精神的, 肉体的苦痛軽減につながる検討・研究を今後も 期待する。

今回発表されました演者の皆さま御苦労様でした.今 後もますます研究発表され活躍されますように!!

質問 (座長)〔演題20〕感度については実測值は表示 されているが，MTF の実測值は？

〔演題21〕 HRC-+G-6についての臨床例について，デ ータはどうか.スライドで示してほしかった。

答（名古屋市立大学病院中央放射線部 住本）グラ フより $2 \mathrm{LP} / \mathrm{mm}$ のところでの值は $\mathrm{KO}-250$ では0.414, KS では0.379でした.

答（医療法人笠寺病院 棚橋）臨床の場合増感紙は G6 が固定されていますがフィルムはオルソタイプを何 種類も使用してみたが演題の如く胃部のみならずその周 辺臟器もよく描写する目的で他の臓器も写し出せるよう 使用しているが胃部撮影にも充分な評価が得られ広く用 いられると思う。

CT II

座長 田村鋒男（金沢大学医学部附属病院）

\section{5. 定量的コンピュータ断層法（QCT）による椎体海綿} 骨の骨量測定

\section{朝日町立泊病院放射線科}

○安達登志樹・小桜吉宏・山本良生

〔目的〕椎体ファントムを用いて CTによる $\mathrm{L}_{1} \sim \mathrm{L}_{3}$ 椎体海綿骨の骨量測定を行い，年齢，性差による骨量の 変化を検討した.

〔結果〕腰椎海綿骨の骨量は男女とも加齢とともに減 少し，年齢との間にある程度高い相関が得られた．特に 女性は男性に比して減少の度合が大きく，閉経期を境に 急激に減少する傾向が認められた。

第一から第三腰椎間の骨量のバラツキは，高年齢層お よびその低值を示すグループに大きく，一椎体のみでな く三椎体の測定を行い検討する必要がある。

装置およびファントムの quality control は, 8 ケ月間 にわたり良好な結果を得た。

26. X線 CT 装置による骨塩量測定法の問題点

富山医科薬科大学附属病院放射線部

○熊谷道朝・嘉戸祥介・伊藤 一 吉田 寿

〔目的〕脊椎骨骨塩校正ファントムによる骨塩量測定 法について大中小三つのサイズの胴体ファントムの椎体 部に中空をあけ, 中空部に既知濃度の $\mathrm{K}_{2} \mathrm{HPO}_{4}$ 溶液を封 入した注射筒を入れ同時に撮影し回帰直線式より求めた $\mathrm{K}_{2} \mathrm{HPO}_{4}$ 濃度（相当量）と既知濃度を比較しその使用上
の問題点を検討した.

〔結果〕 1 脊椎骨骨塩校正ファントムよりアーチファ クトが発生し $\mathrm{K}_{2} \mathrm{HPO}_{4}$ の CT 值は減少する. 2 胴体ファ ントムのサイズが大きくなるほど $\mathrm{K}_{2} \mathrm{HPO}_{4}$ 相当量は減 少する. 3 脊椎骨骨塩校正ファントムと胴体ファントム の密着が悪い場合アーチファクトが発生し $\mathrm{K}_{2} \mathrm{HPO}_{4}$ 相 当量は増加する. $41 \mathrm{ml}$ 当りの $\mathrm{K}_{2} \mathrm{HPO}_{4}$ 濃度が一定で もエタノールを加えると $\mathrm{K}_{2} \mathrm{HPO}_{4}$ 相当量はエタノール が増すごとに減少する。

\section{7. 胃病変における CT 検査法の検討}

大垣市民病院放射線科

○坂野信也・市川秀男・矢橋俊丈

川上文浩・金森勇雄

〔目的〕近年，胃部 CT は病変の範囲，深達部の把握, 転移の検索等, 手術可能か否か判定するために欠くこと のできない検査となってきた. 今回われわれは, 胃病変 におけるCT 検査法, およびガストログラフィンの濃度 については, 各濃度の溶液を $\operatorname{scan} し$, その CT 值を, 各 臓器の CT 值と比較した。

〔結果〕 1. 病変の範囲を知る上で,ガストログラフィ ンの服用が必要であった. 2 . 他臓器との癒着浸潤につい ては，ガストログラフィン未服用 CT も必要であった。

3. ガストログラフィンの濃度は, 単純 CT で $1 \%$, 造影 CT で1.5\%前後が適当であった.

〔結論〕胃部 CT において，ガストログラフィン未服 用単純 CT と服用後造影 CT の組合せが，簡便で最適な 検查法と考えられた。

28. $10 \mathrm{~mm}$ slice 厚 CT scan による膵体尾部膵管の限界 “基礎的検討”

国立津病院
○畑 辰司 -上田 修・佐藤弘泰
山村政隆
国立療養所榊原病院 前沢 稔

〔目的〕膵体尾部膵管など slice 厚内を scan 面に併 走する細い管腔臓器の CT 画像による管腔描出の限界に ついてファントム実験から検討を行ったので報告する.

〔結果〕単純撮影に扔ける膵管と膵体部との CT 值差 を想定した場合， $2 \mathrm{~mm}$ 径の管腔は視覚的に識別がかろ うじて可能な程度であったが，造影撮影を想定した場合 には造影効果の比較的少ない場合でも, $2 \mathrm{~mm}$ 径の管腔 の識別が可能であったまた，脈動，管腔の傾きによる 影響は slice 厚 $10 \mathrm{~mm}$ の場合, partial volume 効果によ りあまり関与していないことがわかった。したがって点 滴法による造影撮影でも管腔に液が充満していれば, 